\title{
THE EFFECT OF WATER REDUCTION IN KRAFT PULP WASHING IN ECF BLEACHING
}

Tânia Cristina Frigieri²*, Gustavo Ventorim ${ }^{3}$ and Jaqueline Silveira Comelato Favaro²

\footnotetext{
${ }^{1}$ Received on 21.05.2016 accepted for publication on 21.09.2016.

${ }^{2}$ Universidade Estadual Paulista, Programa de Pós-Graduação em Engenharia Mecânica, Guaratinguetá, SP - Brasil. E-mail: $<$ taniacfrigieri@yahoo.com.br>and <jaquecomelato@hotmail.com>.

${ }^{3}$ Universidade Estadual Paulista, Itapeva, SP - Brasil. E-mail: <ventorim@itapeva.unesp.br>.

*Corresponding author.
}

\begin{abstract}
The main objective of this work was to study the technical viability of using the cellulose bleaching effluent, at several stages of the process, seeking fresh water reduction in pulp washing, and evaluating its effect on pulp quality. Eucalyptus spp. industrial cellulosic pulp with oxygen was used in this experiment. The same bleaching sequence $\mathrm{D}(\mathrm{E}+\mathrm{P}) \mathrm{DP}$ was performed ten times, under the same conditions (temperature, consistency and time). Counter current washing was used in the bleaching stages, and each sequence was carried out with different washing factors: $9,6,3,0 \mathrm{~m}^{3}$ of distilled water/ton of pulp, trying to reach brightness of $92 \pm 0,5 \%$ ISO. The ten sequences sought to achieve the stability of the effluent organic load, measured by the chemical oxygen demand (COD). Then, the COD results were compared to the brightness ones from the bleached pulp. The evaluated results from the ten sequences and four different washings showed an increasing in COD due to the organic load accumulation, resulting from the reuse of effluent from previous sequences. This COD increasing provided the lower brightness results during the cycles, besides the water reduction, evidencing the necessity of washing between bleaching stages. In this study, the obtained result for the pulp washing up to $3 \mathrm{~m}^{3} / \mathrm{t}$ was tolerable and even recommended. On the other hand, the pulp without any washing $\left(0 \mathrm{~m}^{3} / \mathrm{t}\right)$, due to the lack of enough brightness, it is commercially unviable.
\end{abstract}

Keywords: Pulp; Bleaching; Eucalyptus.

\section{O EFEITO DA REDUÇÃo DE ÁGUA NA LAVAGEM DA POLPA KRAFT NO BRANQUEAMENTO ECF}

\begin{abstract}
RESUMO-O objetivo principal do presente trabalho foi estudar a viabilidade técnica de se usar o efluente da lavagem do branqueamento da celulose, nas diversas etapas do processo, visando uma redução no consumo de água fresca na lavagem da polpa avaliando seu efeito na qualidade da polpa. Foi utilizada polpa celulósica industrial de Eucalyptus spp. deslignificada com oxigênio. Foi feita a mesma sequência de branqueamento $D(E+P) D P$ dez vezes, nas mesmas condições (temperatura, consistência e tempo). Utilizou-se a lavagem em contra-corrente nos estágios de branqueamento, cada sequência foi feita com um diferente fator de lavagem: 9, 6, 3 e $0 \mathrm{~m}^{3}$ de água destilada por tonelada de polpa, buscando atingir a alvura de $92 \pm 0,5 \%$ ISO. As dez sequências realizadas foram uma busca da estabilidade da carga orgânica do efluente medida pela DQO e então comparados os resultados da DQO com os resultados da alvura da polpa já branqueada. Os resultados avaliados das dez sequências e nas quatro diferentes lavagens mostrou o aumento da DQO por causa do acúmulo da matéria orgânica decorrente da reutilização dos efluentes das sequências anteriores. Este aumento da DQO fez com que os resultados da alvura baixassem durante os ciclos e também na redução da água de lavagem, provando a necessidade de que haja lavagem entre os estágios de branqueamento. Neste trabalho o resultado da lavagem até $3 \mathrm{~m}^{3} / \mathrm{t}$ de polpa foi tolerável e ainda recomendável, já para a polpa sem lavagem ( $0 m^{3} / t$ de polpa), por não alcançar alvura suficiente, é inviável comercialmente.
\end{abstract}

Palavras-chaves: Celulose; Branqueamento; Eucalipto. 


\section{INTRODUCTION}

According to Furtado (2008), the pulp production is one of the highest water consumer within industrial sectors. Through intelligent changes in the various productive sections, the pulp market tends to decrease effluent generation by adopting advanced reuse technologies.

As stated by Souza (2002), environmental pressures, together with economic issues, forced to reduce the water consumption in the pulp mills in the last decades and, consequently, decrease the generated volume of liquid effluent to be treated and then released into the environment.

In the bleaching sector of the pulp mill, among the several stages that constitute the Kraft process, the reuse of water and the preservation or recovery of substances is of great interest, as it is the largest pollutant generator in the liquid effluent (COSTA et al., 2006).

In agreement with Almeida et al. (2008), washing between the bleaching stages, besides separating the solubilized material from the pulp and exposing new surfaces to the action of the bleaching reagents, reduces the consumption of reagents used in the next bleaching stage.

After washing, the pulp is pressed. This stage removes much of the effluent to be used in new washings of other bleaching stages. This water from the process will eliminate the use of fresh water and seek to avoid the influence on the efficiency of the pulp bleaching process.

The technology of the press equipment is essential for fresh water reduction in the process and in the efficiency of the circuits in industries, since the evolution between the washer filter, the diffuser and the press is considerable, when compared to the final consistency of the pulp.

Organic soluble components from raw materials and chemicals used in the processes contribute to a higher Chemical Oxygen Demand (COD) and Adsorbable Halogenated Compounds (AOX) (RANGANATHAN et al., 2007).

The issue with the environment determines the evolution of bleaching processes, such as reduction of chemical consumption and pollutant load in the effluent, improvement of pulp brightness, and mainly, minimization of the volume to be sent to the effluent treatment plant (ETP). In addition, another factor of great importance is the quality of the effluent that is released in the watercourses (THAKORE et al., 2000; COLODETTE; SANTOS, 2015).

According to Mountter (2015), one of the main criteria in organic load characterization of bleaching effluents is the COD. It is of high potential polluting and important in the evaluation of its treatability and the efficiency of the effluent treatment. Closed-cycle bleaching system, as explained by Gleadow et al. (1993) apud Freddo et al. (1999), has to present monitoring and transition metal controlling, improvement in the concentration and evaporation of liquors, bleaching effluents recycling, alternative processes to the current ones and reduction of effluents.

The present work focuses on fresh water reduction in the process by promoting new technologies and creating the necessary tools to design closedcycle bleaching plants. In addition, it promotes the industry socially with the final product quality, within the established environmental conditions.

Reducing water consumption aims to solve not only environmental concerns, but also to provide greater economic efficiency in the production of Kraft pulp.

The main objective of this work was to study the use of the effluents generated in the pulp bleaching washing press, within the stages of the bleaching process, aiming at fresh water reduction during pulp washing, evaluating its effect on the pulp and the bleaching effluent quality.

\section{MATERIALAND METHODS}

The Kraft pulp used for bleaching was delignified with oxygen from a pulp and paper mill in the sector.

The applied bleaching sequence was ECF - D0 $(\mathrm{E}+\mathrm{P}) \mathrm{D} 1 \mathrm{P}$. The bleaching was carried out in four identical pulp samples and in each one of them, the same time conditions were used for D0 30 minutes, $(\mathrm{E}+\mathrm{P}) 60$ minutes, $\mathrm{D} 1180$ minutes and $\mathrm{P} 120$ minutes. The temperature was $60,70,70$, and $90^{\circ} \mathrm{C}$, respectively, at each bleaching stage. In the acidic stages, H2SO4 was added for $\mathrm{pH}$ control and in the alkaline stages, $\mathrm{NaOH}$ was added. 
The pulp consistency was adjusted to $10 \%$ in the four samples and at all stages by adding the effluent generated in the sequences made previously in each bleaching process. Pre-established chemical reagents were added, along with the effluent, for each stage and the bleaching was carried out in polyethylene bags.

The use of the effluents to adjust the bleaching consistency and its respective washings, proposing water reduction, was performed ten times with the same process conditions. The achievement of the bleaching repetitions using the effluent from the previous sequence was a simulation of the closed-cycle performed in the industry.

\subsection{Washings}

At the first bleaching sequence, the stages with distilled water for both the consistency adjustment and for pulp washing were performed. After the generation of the effluents, during this first bleaching sequence, the effluents generated in each bleaching stage were reused for the next sequences.

At the end of each bleaching stage, the pulp was washed with different amounts of effluent/effluent or effluent/distilled water $\left(9,6,3\right.$ and $\left.0 \mathrm{~m}^{3} / \mathrm{t}\right)$ with the four samples of the research.

The washing was intended to provide the reuse of the generated effluent in each previous bleaching sequence.

The first bleaching stage consists in additions of chemical reagents and $\mathrm{D}_{0}$ effluent (generated during the previous $D_{0}$ stage) for the adjustment of the consistency of $10 \%$ of pulp. The procedure repeats in the other stages of the bleaching.

After each bleaching stage, $50 \mathrm{~mL}$ of residual liquor was removed for effluent analysis (COD). In the following step, the effluent samples were removed, and the pulp was washed. The pulp washing in nylon cloth bags was carried out with different volumes of washing water for each one of the four samples, with respectively $9,6,3$ and 0 (zero) $\mathrm{m}^{3}$ of distilled water and/or effluent per tonne of pulp.

Next, the pulp centrifugation for effluent collection was performed, to be used in the consistency and washing of next stages.

Table 1 details the washing water distribution in each of the four pulp samples. In $\mathrm{D}_{0}$ stage washing, using $9 \mathrm{~m}^{3} / \mathrm{t}(1800 \mathrm{~mL})$, the washing water was divided into $900 \mathrm{~mL}$ of $\mathrm{D}_{0}$ effluent and $900 \mathrm{~mL}$ of D1 effluent, from respective stages of the previous bleaching sequence. This conduct was repeated up to $\mathrm{P}$ stage, according to Table 1 . This same procedure was replayed for washings with 6 and $3 \mathrm{~m}^{3} / \mathrm{t}$.

After the pulp washing, samples were collected for the preparation of sheets, suitable for pulp brightness analysis. By mixing the residual liquor collected from each bleaching stage, the COD effluent analysis were performed.

The pulp analysis methods used were the TAPPI standards, for paper sheets production (205 sp 95) and brightness (525 om 92), and the methods of effluent analysis were achieved according to the CPPA standard for COD analysis (H 3P).

\section{RESULTS}

After the bleaching and analysis of the pulp and generated effluent, the COD $(\mathrm{mg} / \mathrm{L})$ data were compared with the brightness results (\% ISO).

The results were analyzed according to the washing water reduction $\left(9,6,3\right.$ and $\left.0 \mathrm{~m}^{3} / \mathrm{t}\right)$, and for each of the four types of washing, the bleaching sequence was performed ten times.

Table 1 - Distribution of washing water volume at each stage of bleaching.

Tabela 1 -Distribuição do volume de águas de lavagem em cada estágio do branqueamento.

\begin{tabular}{|c|c|c|c|c|c|c|c|}
\hline & & & & & & & \\
\hline STAGES & $9 m^{3 /}$ & $\mathrm{mL})$ & $6 \mathrm{~m}^{3} / \mathrm{t}$ & $0 \mathrm{~mL})$ & $3 \mathrm{~m}^{3}$ & $\mathrm{~mL})$ & $0 \mathrm{~m}^{3} / \mathrm{t}$ \\
\hline & $900 \mathrm{~mL}$ & $900 \mathrm{~mL}$ & $600 \mathrm{~mL}$ & $600 \mathrm{~mL}$ & $300 \mathrm{~mL}$ & $300 \mathrm{~mL}$ & - \\
\hline $\begin{array}{c}\mathrm{D}_{0} \\
(\mathrm{E}+\mathrm{P})\end{array}$ & $\begin{array}{c}\mathrm{D}_{\mathrm{o}} \\
(\mathrm{E}+\mathrm{P})\end{array}$ & $\begin{array}{l}\mathrm{D}_{1} \\
\mathrm{P}\end{array}$ & $\begin{array}{c}\text { Do } \\
(E+P)\end{array}$ & $\begin{array}{l}\mathrm{D}_{1} \\
\mathrm{P}\end{array}$ & $\begin{array}{c}\mathrm{D}_{\mathrm{o}} \\
(\mathrm{E}+\mathrm{P})\end{array}$ & $\begin{array}{l}\mathrm{D}_{1} \\
\mathrm{P}\end{array}$ & - \\
\hline $\mathrm{D}_{1}$ & $\mathrm{D}_{1}$ & Water & $\mathrm{D}_{1}$ & Water & D1 & Water & - \\
\hline $\mathrm{P}$ & $\mathrm{P}$ & Water & $\mathrm{P}$ & Water & $\mathrm{P}$ & Water & - \\
\hline
\end{tabular}


The brightness was measured in all pulp samples of the different washing factors with the four stages of the process $(\mathrm{D} 0,(\mathrm{E}+\mathrm{P}), \mathrm{D} 1$ and $\mathrm{P})$, and with the ten bleaching sequences.

In Figure 1, the data obtained in the D0 stages were joined and comparisons of the ten sequences of the closed-cycle were made, along with the different washings of $9,6,3$ and $0 \mathrm{~m}^{3} /$ ton of pulp, respectively.

It is observed that the brightness at the four types of washing (Figure 1 - A, B, C and D) decreases as the amount of water reduces. The brightness of the first sequence compared among the four graphs, decreases due to the amount of accumulated organic matter. The pulp washed with the highest amount of water $\left(9 \mathrm{~m}^{3} / \mathrm{t}\right)$ had a lower accumulation of carry over, compared to pulp without any washing $\left(0 \mathrm{~m}^{3} / \mathrm{t}\right)$.

In the same way, the pulp brightness at the last sequence of the four graphs also decreased following the same previous design. It is at this stage of bleaching $\left(D_{0}\right)$ that the lignin is more fragmented and the pulp bleaching takes place by reactions with $\mathrm{ClO}_{2}$. This lower pulp brightness occurs because of the large amount of lignin that is still present in the pulp, when compared to the next stages of the bleaching sequence.

Next, Figure 2 demonstrates the stages $(E+P)$ with the different washings.

The brightness at this stage $(\mathrm{E}+\mathrm{P})$ had a larger decrease during the ten sequences when compared to D0 stage. At this stage (D0), the pulp brightness loss between the first and the last sequence was $3.3 \%$ ISO brightness, whereas for the stage $(\mathrm{E}+\mathrm{P})$, it was $5.9 \%$ brightness. This higher decrease in brightness was due to the higher COD content from the extraction of the lignin that reacted with the $\mathrm{ClO} 2$ in the previous stage, which consumes hydrogen peroxide that acts as a bleach in the pulp.

In addition, this research decreased the use of fresh water during pulp washing, which increased the COD between the different sequences, as shown in graphs A and B (Figure 1), in which the washing is more efficient than in $\mathrm{C}$ and $\mathrm{D}$ graphs (Figure 2).
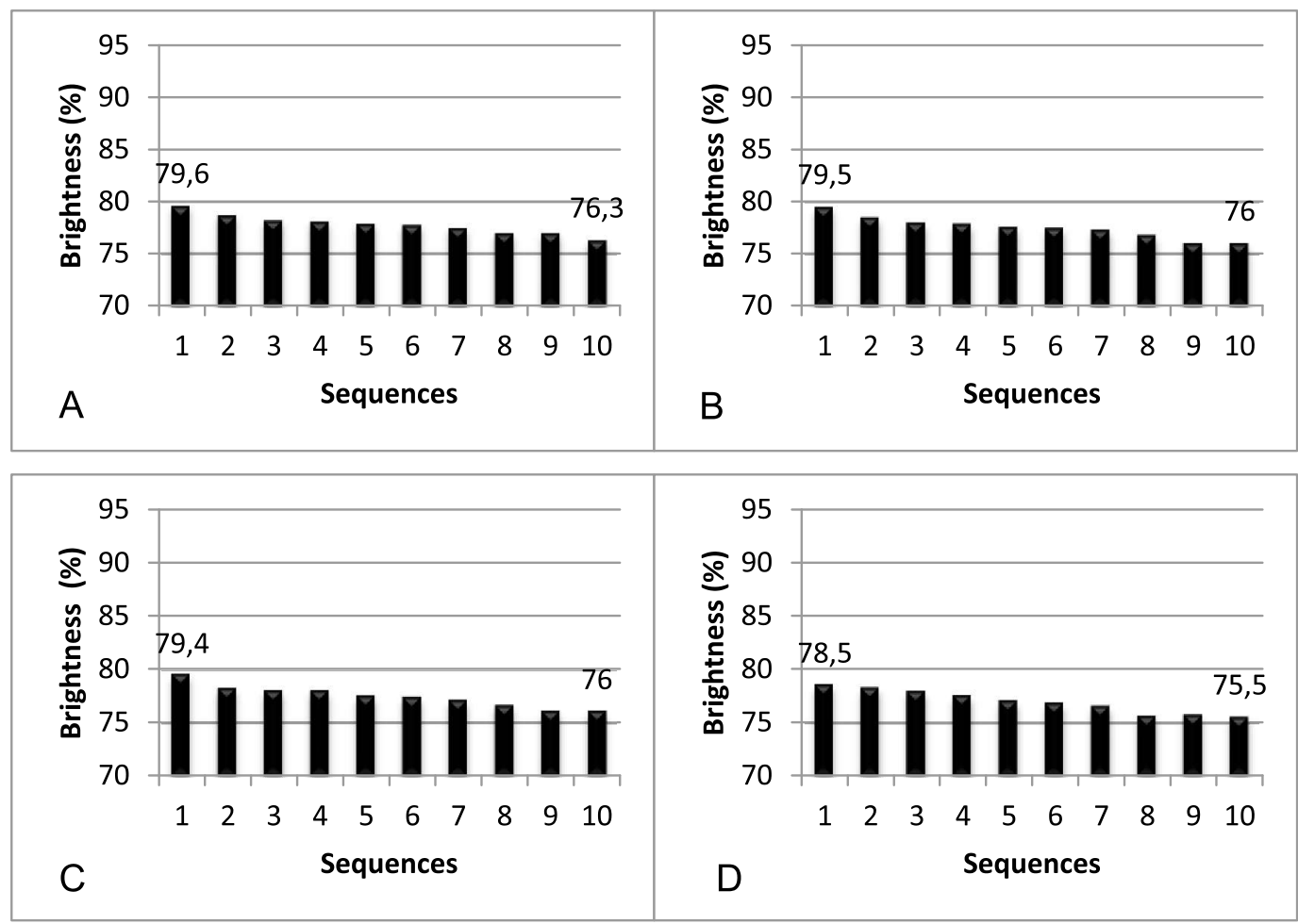

Figure 1 - Comparison of washings from the ten repetitions on stage D0: A $\left(9 \mathrm{~m}^{3} / \mathrm{t}\right), \mathrm{B}\left(6 \mathrm{~m}^{3} / \mathrm{t}\right), \mathrm{C}\left(3 \mathrm{~m}^{3} / \mathrm{t}\right)$ and D $\left(0 \mathrm{~m}^{3} / \mathrm{t}\right)$. Figura 1 - Comparação das lavagens nas dez repetições no estágio Do: $A\left(9 m^{3} / t\right), B\left(6 m^{3} / t\right), C\left(3 m^{3} / t\right)$ e $D\left(O m^{3} / t\right)$.

Revista Árvore, Viçosa-MG, v.40, n.6, p.1091-1098, 2016 

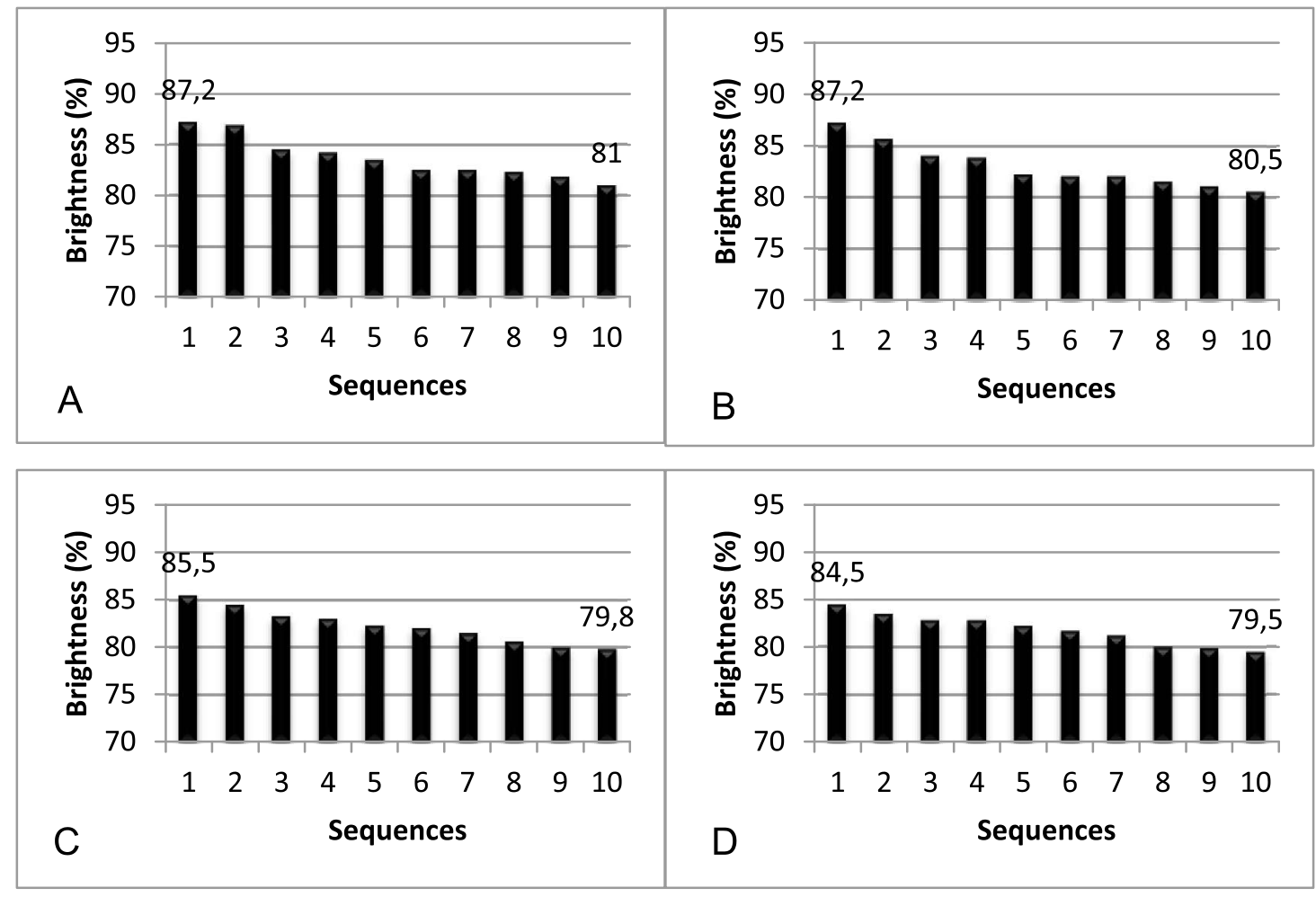

Figure 2 - Comparison of washings from the ten repetitions on stage $(E+P): A\left(9 m^{3} / t\right), B\left(6 m^{3} / t\right), C\left(3 m^{3} / t\right)$ and $D$ $\left(0 \mathrm{~m}^{3} / \mathrm{t}\right)$.

Figura 2 - Comparação das lavagens nas dez repetições no estágio $(E+P)$ : A $\left(9 \mathrm{~m}^{3} / \mathrm{t}\right), \mathrm{B}\left(6 \mathrm{~m}^{3} / \mathrm{t}\right), \mathrm{C}\left(3 \mathrm{~m}^{3} / \mathrm{t}\right)$ e $\mathrm{D}\left(0 \mathrm{~m}^{3} / \mathrm{t}\right)$.

Figure 3 shows the results of D1 stage between the first and the last bleaching sequence, which are lower ( $\ddot{A} 2.7 \%$ ISO brightness), when compared to the previous stages.

This minor drop is consistent with the lower amount of lignin to be withdrawn from the pulp at this stage, thereby causing less difference in the brightness among the ten repetitions of the bleaching sequence.

Finally, in the last bleaching stage (P), it is observed during brightness analysis in Figure 4 that from the first to the last bleaching sequence, there was a decrease of $3.7 \%$ ISO brightness.

This has happened because it is the last stage of bleaching, in which the pulp is close to $90 \%$ ISO and this high brightness is more sensitive to organic matter.

The most abrupt drop in brightness occurred on graph D (Figure 4), without any washing, showing that the amount of organic matter accumulated in the ten sequences caused lower brightness, compared to other sequences.

\section{DISCUSSION}

The industrial cellulosic pulp used, delignified with oxygen, had the advantage of having $50 \%$ of the residual lignin removed early in the bleaching process. As reported by Colodette et al. (2002) apud Del Grande (2004), this characteristic of the process promotes a great pollutant load reduction, mainly due to the global decrease in color and lower biochemical oxygen demand (BOD) of the effluents.

The water closed-cycle system increases the COD load, and consequently, the pulp brightness decreases (SOUZA, 2005). The brightness results, even with its drop due to COD, remained above the market classification limit of $>90 \% \pm 0.5$ ISO, in consonance with Moreira (2010).

Revista Árvore, Viçosa-MG, v.40, n.6, p.1091-1098, 2016 

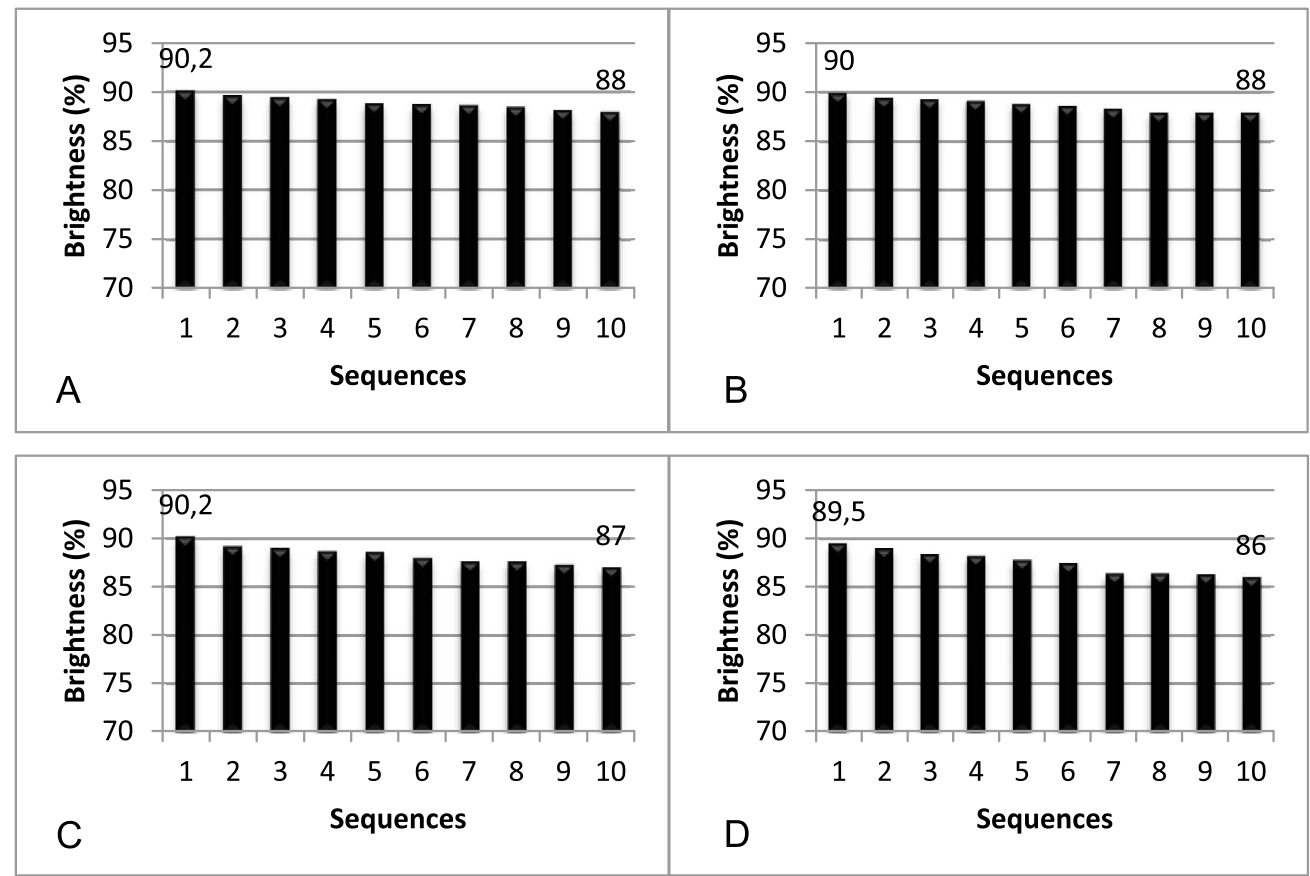

Figure 3 - Comparison of washings from the ten repetitions on stage D1: A $\left(9 \mathrm{~m}^{3} / \mathrm{t}\right), \mathrm{B}\left(6 \mathrm{~m}^{3} / \mathrm{t}\right), \mathrm{C}\left(3 \mathrm{~m}^{3} / \mathrm{t}\right)$ and D $\left(0 \mathrm{~m}^{3} / \mathrm{t}\right)$.

Figura 3 - Comparação das lavagens nas dez repetições no estágio $D 1: A\left(9 m^{3} / t\right), B\left(6 m^{3} / t\right), C\left(3 m^{3} / t\right)$ e $D\left(O m^{3} / t\right)$.
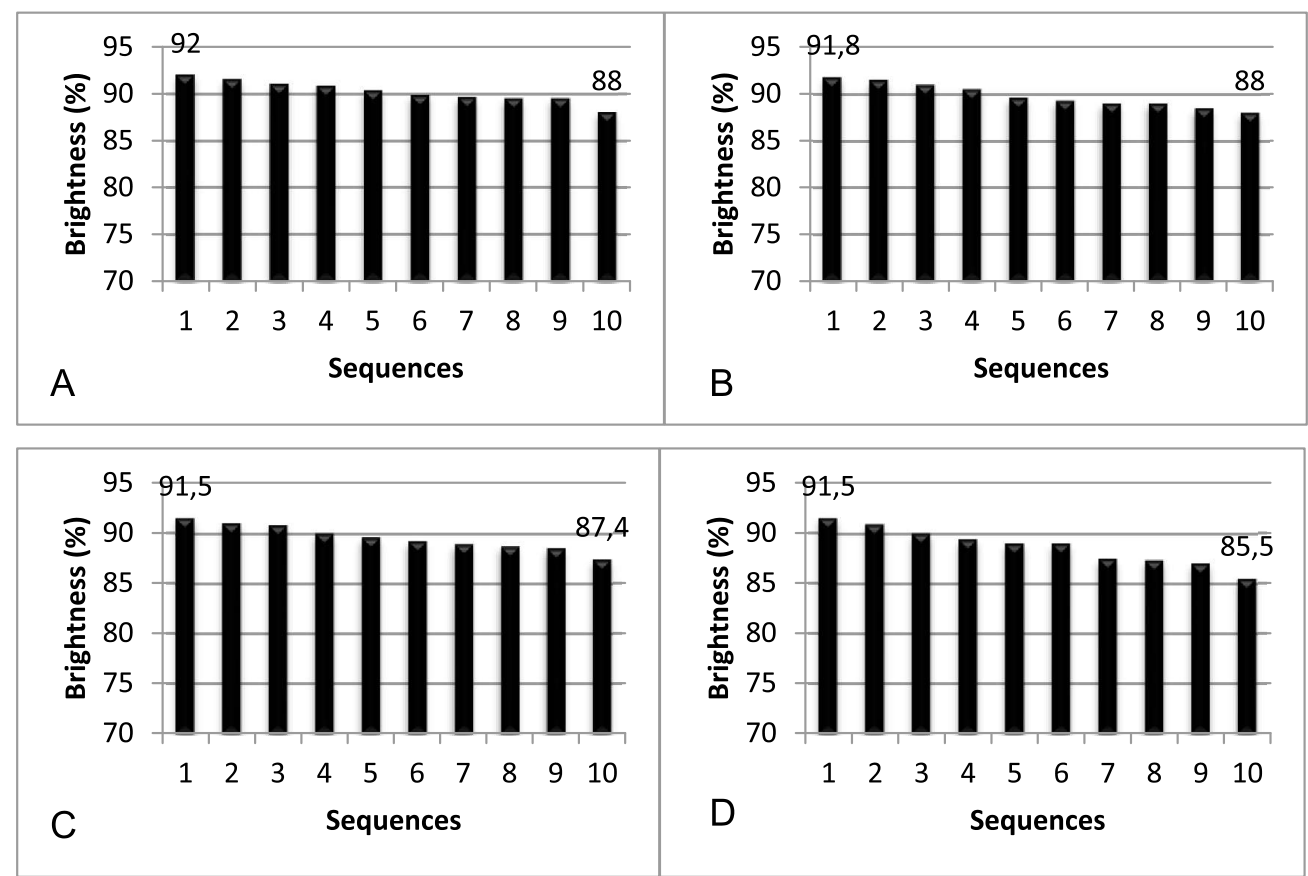

Figure 4 - Comparison of washings from the ten repetitions on stage P: A $\left(9 \mathrm{~m}^{3} / \mathrm{t}\right), \mathrm{B}\left(6 \mathrm{~m}^{3} / \mathrm{t}\right), \mathrm{C}\left(3 \mathrm{~m}^{3} / \mathrm{t}\right)$ and D $\left(0 \mathrm{~m}^{3} / t\right)$. Figura 4 - Comparação das lavagens nas dez repetições no estágio $P: A\left(9 m^{3} / t\right), B\left(6 m^{3} / t\right), C\left(3 m^{3} / t\right)$ e $D\left(O m^{3} / t\right)$.

Revista Árvore, Viçosa-MG, v.40, n.6, p.1091-1098, 2016 
The bleaching technology, according to Brasileiro (2005), has obtained brightness of approximately $85 \%$ ISO for hardwoods, after the use of hydrogen peroxide, as observed in Figure 2-C; even with the use of the effluent to adjust the consistency and pulp washing.

The brightness of the last bleaching stage, when washing was performed with $3 \mathrm{~m}^{3} / \mathrm{t}$, shown in Figure 4-C, indicates approximately $87.5 \%$ ISO, and is acceptable for many customers. Nevertheless, the pulp that lacks washing during the ten bleaching sequences could not be commercialized, as it is not within the parameters required by the clients.

Results obtained by Costa et al. (2006) showed that after the second bleaching cycle, brightness was stabilized. This fact indicates that the COD accumulation that occurred after the second cycle had no significant effect on this pulp property.

As there was a beginning of COD stabilization, as observed previously, it was also predicted that the brightness stabilization would take place, but it did not. Conforming to Costa et al. (2006), after the second bleaching stage, at the closed-cycle, the brightness result was stabilized. This fact indicates that the COD accumulation that occurred after the second stage had no significant effect on this pulp property.

\section{CONCLUSION}

In accordance with the objective of the present work, with the reuse of the effluent from each stage, it is possible to close the cycle in the bleaching process, even with COD increased.

There was also a real fresh water reduction in the stages that used 9 and $6 \mathrm{~m}^{3} / \mathrm{t}$ of effluent during the washing, and the pulp did not present great loss in the final quality.

The brightness of each bleaching stage, between the same wash and in different washings, gradually decreased, but at the stages with 9 and $6 \mathrm{~m}^{3} / \mathrm{t}$ of effluent during the wash obtained the desired commercial brightness.

It was found in this work that bleaching with 3 $\mathrm{m}^{3} / \mathrm{t}$ of washing effluent or without washing between the bleaching stages, even with the press use, is unfeasible until now, as the brightness showed inferior result to commercially recommended.

\section{REFERENCES}

ALMEIDA,A.M.; PINHEIRO,A.R.O.; CARNEIRO R.; SILVA, R.C. Processos limpos no branqueamento de polpa celulósica. 2008. TELÊMACO BORBA, PR. Faculdade de Telêmaco Borba (FATEB), Engenharia Química Ênfase em Celulose e Papel, Telêmaco Borba PR, 2008.

BRASILEIRO, L.B.; COLODETTE, J.L.; PILÓVELOSO, D. A utilização de perácidos na deslignificação e no branqueamento de polpas celulósicas. Química Nova, v.24, n.6, p.819$829,2001$.

COLODETTE, J.L.; SANTOS, V.L.S. Princípios gerais do branqueamento. In: COLODETTE, J.L; GOMES, F.J.B. Branqueamento de polpa celulósica: da produção da polpa marrom ao produto acabado. Viçosa, MG: Universidade Federal de Viçosa, 2015. p.173-202.

COSTA, M.M.; COLODETTE, J.L.; LANDIM, A.; SILVA, C.M.; CARVALHO, A.M.M.L. Nova tecnologia de branqueamento de celulose adaptada ao fechamento do circuito de água. Revista Árvore, v.30, n.1, p. 129-139, 2006.

DEL GRANDE, M.H. Racionalização do uso de água na indústria de Celulose: $\mathrm{O}$ caso Bahia Pulp. 2004. 158f. Dissertação (Mestrado Proficional em Gerenciamento e Tecnologia S Ambientais no Processo Produtivo) Escola Politécnica da Universidade Federal da Bahia, Salvador, 2004.

FREDDO, A.; FOELKEL, C. E. B.; FRIZZO, S. M. B.; SILVA, M. C. M. Elementos minerais em madeiras de eucaliptos e acácia negra e sua influência na indústria de celulose Kraft branqueada. Ciência Florestal, n.1, v.9, p.193-209, 1999.

FURTADO, M. Tratamento de efluentes: Celulose e papel economizam água com produção limpa e reuso. Revista Química e Derivados, n 471, mar. 2008. [acessado em: 25 ago. 2010.

Disponível em: http://www.ecoaguas.com.br/docs/ tratamento_de_efluentes_noticia.pdf.

MOUNTEER, A.H. Impacto ambiental da operação de branqueamento. In: COLODETTE, J.L.; GOMES, F.J.B. Branqueamento de polpa

Revista Árvore, Viçosa-MG, v.40, n.6, p.1091-1098, 2016 
celulósica: da produção da polpa marrom ao produto acabado. Viçosa, MG: Universidade Federal de Viçosa, 2015. p.767-780.

MOREIRA, L.J. Minimização de efluentes em uma fábrica de polpa Kraft losolids® branqueada de eucalipto. 2010. 23f. Dissertação (Mestrado Proficional em Tecnologia de Celulose e Papel) - Universidade Federal de Viçosa, Viçosa, MG, 2010.

RANGANATHAN, K.; JEYAPAUL, S.; SHARMA, D.C. Assessment of water pollution in different bleaching based paper manufacturing and textile dyeing industries in India. London: Springer Science, 2007.

SOUZA, L.C. O princípio do fechamento de circuito das águas e seus efeitos no processo de fabricação de celulose kraft branqueada, no processo de fabricação de papel e nas características e tratabilidade do efluente. 2002. 72f. Dissertação (Mestrado Proficional em Tecnologia de Celulose e Papel) Universidade Federal de Viçosa, Viçosa, MG, 2002.

SOUZA, L. C.. Recirculação do filtrado alcalino do branqueamento para o estágio de deslignificação com oxigênio de polpa Kraft e sua conseqüência no processo. 2005. $223 \mathrm{f}$. Tese (Doutorado Proficional em Tecnologia de Celulose e Papel), Universidade Federal de Viçosa, Viçosa, 2005.

THAKORE, A., OEI, J., HEIMBURGER, S.

Significant improvements in ECF bleaching using a minimum capital approach to better filtrage MGMT. in: International Bleaching Conference. Proceedings... Canadá, 2000. 